\title{
Attitude reports with and without true belief *
}

\author{
Deniz Özyıldız \\ UMass, Amherst
}

\begin{abstract}
In Turkish, attitude verbs or embedded clauses cannot be identified as factive presupposition triggers. Yet, the presupposition is observed when certain verbs embed nominalized clauses. I propose to derive the inference globally in the composition, rather than encoding it as a lexical property of certain "triggers."
\end{abstract}

Keywords: factive inference, knowledge and belief reports, situation semantics

\section{Setting the stage}

In Turkish, with certain attitude verbs, the availability of a factive inference is conditioned by the syntactic form of the embedded clause. Let me refer to this phenomenon, in (1), as a "factivity alternation." Sentence (1a) is the "factive," and sentence (1b) is the "non-factive alternant."

a. Tunç [Hillary’nin kazan-dığın-1] biliyor.

T. H. win-NMZ-ACC knows

Tunç knows that Hillary won. $\rightarrow$ Hillary won. $\quad$ (factive)

b. Tunç [Hillary kazan-dı diye] biliyor.

T. H. win-PST DIYE knows

Tunç believes that Hillary won. $\not \rightarrow$ Hillary won. (non-factive)

Based on contrasts like (1), I argue that the factive inference is not triggered by particular lexical or functional items, but that it arises in the syntactic/semantic composition. A unified implementation is given, and along the way, various aspects of the contrast in (1) are described.

It is almost uncontroversial that the knowledge report (2a), but not the belief report (2b), implies the truth of the attitude proposition.

* Many many thanks to my advisors Rajesh Bhatt and Vincent Homer, to the anonymous reviewers who have helped improve this project, to those who have provided support and helpful discussion: İsa Kerem Bayırlı, Ömer Demirok, Kajsa Djärv, Paul Égré, Aurore Gonzalez, Lisa Green, Paloma Jeretič, Natasha Korotkova, Angelika Kratzer, Paul Marty, Sophie Moracchini, Jérémy Pasquereau, Benjamin Spector, and Katerina Vostrikova; and finally to audiences at UMass, ECO5 2016, Tu+2, ESSLLI 2016, and SALT 27.

C2017 Özy1ldız 
(2) a. Tunç knows that Hillary won.

b. Tunç believes that Hillary won.

This is the factive inference and verbs like "know" are called factive verbs. The words "implies" and "inference" are used as a neutral cover term for entailments, presuppositions, implicatures, and the like. These are some of the many ways that something can be implied. The relevant notion here must minimally account for the fact that a speaker who says (2a) contradicts herself if she goes on to say "but Hillary didn't win." This suggests entailment. Some authors replace or supplement entailment with other kinds of inferences, usually with presupposition.

Much research into the factive inference focuses on its projective behavior. This paper is not directly about projection. It is about how the inference arises in root declaratives like (1) and (2). The question, for English, already has a few answers:

The minimal difference between (2a) and (2b) suggests that the verb "know" is responsible for the factive inference. Therefore, some build the inference into the denotation of the verb (Hintikka 1962; Percus 2006). Others export the inference into the denotation of the complement clause (Kiparsky \& Kiparsky 1970; Kratzer 2006). In this case, a verb like "know" is factive in the sense that it selects a factive complement clause. These two views have something in common: The factive inference is encoded in a particular linguistic object (the verb or the clause), whose presence in the structure is a sufficient condition for observing it.

According to a third view, motivated by contrasts like (3) from Schulz (2003), the inference arises in the composition between certain verbs (including "know" or "forget," but not "believe") and a certain type of clause. The guiding observation is that "forget," for instance, is factive with a that-clause, but not with an infinitival. ${ }^{1}$

a. Mary forgot that she filled the tank. $\rightarrow$ Mary filled the tank.

b. Mary forgot to fill the tank. $\nrightarrow$ Mary filled the tank.

The empirical contribution of this paper is a description of Turkish belief reports, focusing on how their truth and use conditions are affected by the type of clause that they embed. In particular, the factivity alternation, introduced in (1) and further described in section 2, brings support to the third view that the factive inference arises in the composition. Section 3 is dedicated to the formal implementation of the idea, and shows how to derive factive and non-factive attitude reports in the composition. Section 4 identifies and addresses open issues. Section 5 concludes.

1 "Know" does not seem to participate in this alternation. "Mary knows to fill the tank" presupposes that someone has to fill the tank. This is a factive, rather than an implicative use Karttunen (1971), though the proposition presupposed is not exactly the one seen on the surface. White (2014) might be relevant here, who proposes to reduce the implicative entailment to the factive presupposition. 
Attitudes with(out) true belief

\section{The factivity alternation in Turkish}

\subsection{Two necessary conditions for the factive inference}

Examples (1a) and (1b) are repeated below. These are attitude reports introduced by the verb bil- ("know" in the dictionary) that equally attribute to Tunç the belief that Hillary won. The reports differ in the syntactic form of the embedded clause, which is a "nominalized" clause in (1a), and a "tensed" clause in (1b).

a. Tunç [Hillary'nin kazan-dığın-1] biliyor.

T. H. win-NMZ-ACC knows

Tunç knows that Hillary won.

(factive)

b. Tunç [Hillary kazan-dı diye] biliyor.

T. H. win-PST DIYE knows

Tunç believes that Hillary won.

(non-factive)

Nominalized clauses feature a main predicate that hosts nominal morphology and a subject that is canonically in the genitive. Tensed clauses are indistinct from root clauses, except that they are sometimes introduced by the morpheme diye. (By calling these clauses "tensed," I do not imply that nominalizations are tenseless.) The type of embedded clause makes an interpretive difference: While it feels selfcontradictory to utter (4) after (1a), which denies the embedded proposition, it is perfectly acceptable to do so after (1b).

\section{Ama kazan-ma-d1. \\ but win-NEG-PST.3S}

But she didn't win. \# after (1a); $\checkmark$ after (1b), (5a) and (5b)

This test suggests that the embedded proposition is implied in (1a), which is factive, but not in (1b), which is non-factive. ${ }^{2}$ Non-factive reports are non-presuppositional and non-veridical. They are compatible with the falsity of the attitude proposition (and this is sometimes conversationally implicated). They are not non-factive in the sense that the presupposition is accommodated (Lewis 1979; Heim 1988). They are also not contra-factive (Kierstead 2013; Glass 2016; Holton 2017).

As far as I know, this contrast is not discussed in the Turkish literature (though see examples in Şener 2008). Similar contrasts reported for other languages are largely unaccounted for (Moulton 2009; Abrusán 2011). Whether factivity alternations form a unified phenomenon cross-linguistically is a topic for further research.

Because the alternation is conditioned by embedded clause type, a natural interpretation of the contrast in (1) is that bil-is not a factive verb. A second conclusion

2 This is a slightly simplified description of the facts. See section 4.3 for the complications. 
is that the inference might be contributed by the nominalized clause in (1a). Tensed clauses would not contribute the inference, which would explain the non-factivity of (1b). ${ }^{3}$ Further discussion of competing analyses is provided in Özyıld1z (2016).

That nominalizations could be responsible for the factive inference receives support from the literature (Moulton 2009; Kastner 2015; Hanink \& Bochnak 2017). Yet, there are many verbs like düşün- ("think") that compose with nominalized clauses without giving rise to the inference. This is unexpected if nominalizations were factive across the board. Example (5a) illustrates. The report is felicitously followed up by (4), the denial of the embedded proposition. Example (5b) shows that düşün also embeds tensed clauses, again without yielding the inference.

a. Tunç [Hillary’nin kazan-dığın-1] düşünüyor.

T. H. win-NMZ-ACC thinks

Tunç thinks that Hillary won.

(non-factive)

b. Tunç [Hilari kazan-d1 diye] düşünüyor.

T. H. win-PST.PFV DIYE thinks

Tunç thinks that Hillary won.

(non-factive)

Can the conclusion that there are non-factive nominalizations be strengthened into one stating that all nominalizations are non-factive? It is conceptually possible that there might be factive nominalizations in addition to non-factive ones, although these clauses would look identical on the surface. (The same comment applies to that-clauses under "believe," vs. ones under "know.") I acknowledge this possibility, but stick to surface form and assume that we are dealing with a single type of nominalized clause. This clause type is not inherently factive. It gives rise to the inference when it composes with bil-, as in (1a), but not with düşün-, as in (5a). ${ }^{4}$

Summing up, the core contrasts between (1a) and (1b), on the one hand, and between (1a) and (5a) on the other, respectively suggest that the factive inference is not encoded in the lexical semantics of a verb like bil-, and that it is not encoded in

3 The morpheme diye derives from the root de- for "say." Factors that condition its expression are ill-understood. Further research might reveal a significant link between non-factivity and "say" (Grimshaw 2015), but this does not play a role in the present analysis. Indeed, as Jaklin Kornfilt (p.c.) also notes, expressing diye is not required to get non-factive readings under, for instance, bil-. This suggests that diye might not be the "locus" of non-factivity.

(i) Annem [ ben-i Girit'te ] biliyor ama Somali'deyim.

my mother $1 \mathrm{~s}-\mathrm{ACC}$ in Crete know but I'm in Somalia

My mother \{believes, \#knows $\}$ that I'm in Crete but I'm in Somalia.

4 This point, of course is not an argument against the factive complementizers/clause types approach. To get off the ground, such accounts must state that certain attitude verbs select for factive complement clauses, while others select for non-factive ones. 
Attitudes with(out) true belief

the semantics of nominalized clauses. Given that the factive inference $i$ s observed in Turkish, how it arises must be accounted for. Descriptively, its source resides in the interplay between certain verbs and nominalized clauses, and this is what a successful account must capture.

\subsection{The factivity alternation is a general phenomenon}

A broad class of attitude verbs embed both nominalizations and tensed clauses. A subset of them pattern like bil- and participate in the alternation, others pattern like düşün- and do not. Non-exhaustive lists are respectively given in (6a) and (6b) alongside the verbs' dictionary translations.

a. Verbs that participate in the alternation in addition to bil-: hatırla-, "remember"; anla-, "understand"; öğren-, "discover, find out, learn"; gör-, "see"; gözlemle-, "observe"...

b. Verbs that do not participate in the alternation in addition to düşün-: san-, "believe"; um-, "hope"; hayal et, "imagine"; bekle-, "expect"...

These verbs can be placed into the frames in (1) and (5), and followed up by (4), with mostly the expected results. The choice of embedded clause type does not seem to make a difference in the truth and use conditions of attitude reports formed with the verbs in (6b), though further research might reveal some. ${ }^{5}$

For completeness, a verb like unut-, "forget," is incompatible with tensed clauses, and is only used factively. Independent issues arise in testing emotive factives. Finding some variation in the robustness of the inference with the verbs in (6a) should not be surprising. But it would be unexpected to find the verbs in (6b) used factively (leaving aside the possibility of pragmatic presupposition).

These lists suggest an interesting pattern: Verbs that participate in the alternation seem to translate (semi-)factives from familiar languages; And ones that don't, non-factives (Hooper 1975). Whether this 'correlation' is significant, I do not know. ${ }^{6}$ Nothing crucial hinges on it. Were translations for the Turkish attitude verbs lacking, much of the same conclusions drawn here could still be drawn.

The productivity of the factivity alternation, as well as the pattern (taken at face value) displayed by verbs that participate in it, do serve to defuse an account based on accidental homophony. Such an account rests on the assumption that some attitude verbs come in pairs. One member of the pair has a factive semantics, while

5 General differences between nominalized and tensed clauses are described in Şener \& Şener (2011); Özyıldız (2012); Korotkova (2016), with respect to indexical shifting and embedded modality.

6 Many commentators have drawn attention to the fact that the initial title of this work, which fluctuated along the lines of "Knowledge reports with and without true belief," was misleading. See also Hazlett (forthcoming) on the matter. 
the other has a non-factive one. Both members happen to be pronounced the same. For instance, $b i l_{\text {-factive }}$ and $b i l_{\text {-non-factive }}$ would form such a pair. Verbs like düşün-, on the other hand, would only have a non-factive entry. Ultimately, I do not know how to dismiss this option but by appealing to common sense.

\subsection{The factive inference patterns like a presupposition}

The inference projects in Turkish: It is available from under the scope of entailment cancelling operators like negation (with the usual qualifications about projection).

Context (7a) makes the embedded proposition in (7b)/(7c) false, and the discussion of a third person's attitudes relevant. In (7b), negating bil- with a nominalization is odd, while düşün- is acceptable in the same context and frame. Negating attitude reports with either verb and a tensed clause is also acceptable, as seen in (7c).

a. Context: "We must inform Tunç. Hillary lost the election."

b. Tunç [Hillary'nin kazandığını] \{\#bil-m-iyor, $\quad \checkmark$ düşün-m-üyor\}. T. H. win.NMZ know-NEG-PRES think-NEG-PRES

Tunç doesn't \{\#know, $\checkmark$ think \} that Hillary won.

c. Tunç [Hillary kazandı diye] \{bil-m-iyor, düşün-m-üyor\}. T. H. won diye know-NEG-PRES think-NEG-PRES

Tunç doesn't \{believe, think $\}$ that Hillary won.

The report with bil- in (7b) implies that the embedded proposition is true despite negation, which contradicts the premise that Hillary did not win. This suggests that the factive inference is a presupposition, when available. Projection is not observed for the other three attitude reports, presumably due to the fact that their positive counterparts (in (5a), (1b) and (5b)) do not trigger the inference.

\section{Deriving the alternation}

How does an attitude report introduced by a verb like bil-come to imply that the attitude proposition is true only if that proposition is expressed by a nominalization?

The two ground rules that I follow in answering this question are that the factive inference is not packed into the denotation of nominalizations, and that bil-should have a single lexical entry that derives both factive and non-factive attitude reports.

\subsection{Preliminary assumptions}

Assume first that both tensed clauses and nominalizations denote regular propositions, viewed here as predicates of possible situations (Kratzer 1989): 
Attitudes with(out) true belief

$\llbracket$ Hilari kazandı diye $\rrbracket=\llbracket$ Hilari'nin kazandığı $\rrbracket=\lambda \operatorname{s} \cdot \operatorname{win}(s)($ hillary $)$

(Where ' $\lambda s$ s.win $(s)$ (hillary)' is short for

$$
\text { ' } \lambda s . \exists e[e \leq s \wedge \operatorname{win}(e) \wedge \text { agent }(e)=\text { hillary.') }
$$

This treatment glosses over structural differences internal to the clauses and is likely an oversimplification, but one that will do for present purposes.

Assume next that predicates like bil-denote a non-factive de re belief relation about situations as in (9). The formal statement in (9a) is paraphrased in (9b).

(9) For any $w, s \in D_{s}, p \in D_{s t}, x \in D_{e}$ and assignment function $g$ 【bil- $\rrbracket^{g}\left(w_{s}\right)\left(s_{S}\right)\left(p_{s t}\right)\left(x_{e}\right)$ is true iff

a. $\exists R\left[R(x, s, w) \wedge \forall w^{\prime}\left[w^{\prime} \in D O X_{x, w} \rightarrow p\left(l s^{\prime}\left[R\left(x, s^{\prime}, w^{\prime}\right)\right]\right)\right]\right]$

b. There is a suitable acquaintance relation $R^{7}$ such that

i. $x$ is acquainted with $s$ through $R$ at $w$, and

ii. for all $w^{\prime}$ in $x$ doxastic alternatives to $w$ the situation $s^{\prime}$ that $x$ is acquainted with through $R$ at $w^{\prime}$ satisfies $p$.

The function denoted by bil- composes with a situation $w$ at which it is evaluated, a second situation $s$ (the res), a proposition $p$, and an individual $x$ (the attitude holder). It returns true iff the attitude holder is suitably acquainted with the res situation at the world of evaluation, and believes of the res that it satisfies $p$. Given this setup, tensed clauses and nominalizations as defined in (8) may only saturate bil-'s proposition argument, which introduces the content of the attitude. Its res argument is saturated by (often covert) situation pronouns, which, as pronouns, may be referential or bound, or by definite descriptions of situations. With these assumptions, the factive and the non-factive alternant can be derived from a common structure.

The definition in (9) is non-factive in that the situation that the attitude holder is acquainted with in the world of evaluation need not satisfy the belief proposition. In the framework that I am assuming, a proposition is a set of situations that, in general, includes different situations from different worlds. Any given situation is part of a single world (Kratzer 1989; Portner 1992). Assume that there are exactly two worlds $w_{1}$ and $w_{2}$ in our model. The set $\{s \mid \operatorname{rain}(s)\}$ includes situations that are part of $w_{1}$ and ones that are part of $w_{2}$, provided that in both worlds, it is raining somewhere. Furthermore, I assume that if one is acquainted, at world $w$, with a situation $s$, then $s$ is part of $w$. This, along with the previous point, ensures that the belief proposition gets evaluated with respect to the attitude holder's doxastic alternatives.

7 As far as I can tell, the literature usually makes use of acquaintance relations, which should allow for the possibility that one may be acquainted with more than one res. This creates a problem if we are to introduce the res with the iota operator, which requires unicity. Elaborating on this issue is beyond the scope of this paper. I am indebted to Rajesh Bhatt and Vincent Homer for drawing my attention to this point, and also to Emar Maier for helpful discussion. 
Note about (9) that I follow Percus (2000) in assuming the presence of (evaluation) situation pronouns in the syntax. I refer to these as "worlds," to avoid confusion with the res situation. The definition is inspired by one way of implementing the relational analysis of de re belief ascription about individuals (Quine 1956) or times (Abusch 1994; Heim 1994), though I do not need to assume res-movement. It is possible that the present proposal cannot be implemented with concept generators (Percus \& Sauerland 2003). See Charlow \& Sharvit (2014) for an excellent overview. The reader may also consult Kratzer $(1998,2002)$ for reasons to think that there are de re beliefs about situations much like about other object. Any shortcomings of the particular implementation presented here are mine only.

The reason that some verbs like düşün- do not participate in the factivity alternation is captured by the assumption that they do not select for a res argument in their syntax. A standard Hintikkan semantics is provided in (10):

(10) For any $w \in D_{s}, p \in D_{s t}, x \in D_{e}$ and assigment function $g$

$$
\llbracket \text { düşüun- } \rrbracket^{g}(w)(p)(x)=1 \text { iff } \forall w^{\prime}\left[w^{\prime} \in D O X_{x, w} \rightarrow p\left(w^{\prime}\right)\right]
$$

\subsection{Deriving the non-factive alternant}

Example (1b) is repeated below, where bil- introduces a non-factive attitude report. The underlying structure for (1b), given in (11), makes bil-'s res argument visible. That slot is saturated (here) by a phonologically null situation pronoun $s_{7}$. The tensed clause visible on the surface saturates bil-'s proposition argument.

(1b) Tunç [Hillary kazan-dı diye] biliyor.

T. H. win-PST DIYE knows

Tunç believes that Hillary won.

Structure for (1b)

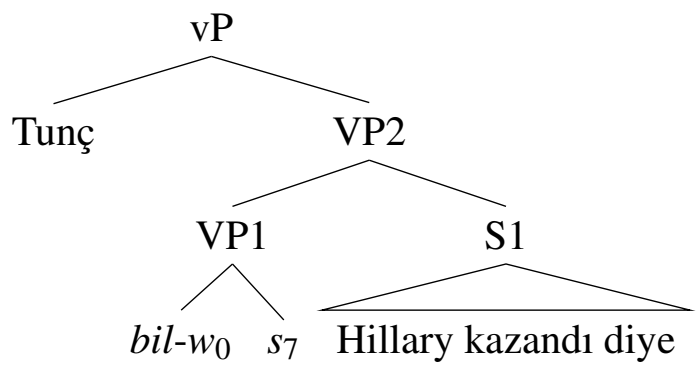

(abstraction over $w_{0}$ omitted)

By successive application of function application, the attitude verb composes with the evaluation world, its res argument $s_{7}$, the proposition denoted by the tensed clause, and the attitude holder. We arrive at the truth conditions stated in (12).

The first conjunct of (12) states that Tunç is acquainted with $g(7)$ at $w_{0}$ through the existentially introduced acquaintance relation $R$. The second conjunct states that 
for every $w^{\prime}$ in Tunç's doxastic alternatives calculated at $w_{0}$, the situation $s^{\prime}$ that he is acquainted with through $R$ at $w^{\prime}$ makes the proposition that Hillary won true. (A consequence of this is that all of Tunç's doxastic alternatives are worlds where Hillary won, hence that Tunç believes that Hillary won.)

$$
\begin{aligned}
& \llbracket \mathrm{vP} \rrbracket=\llbracket \text { bil- } \rrbracket\left(w_{0}\right)\left(s_{7}\right)(\llbracket \mathrm{S} 1 \rrbracket)(t)=1 \text { iff } \\
& \exists R\left[R\left(t, g(7), w_{0}\right) \wedge \forall w^{\prime}\left[w^{\prime} \in D O X_{t, w_{0}} \rightarrow w i n\left(l s^{\prime}\left[R\left(t, s^{\prime}, w^{\prime}\right)\right]\right)(h)\right]\right]
\end{aligned}
$$

The res argument can be valued in different ways. Here is one: Assume that I utter sentence (1b) after saying "Trump won the election, but..." Then, a value for the res can be found in the discourse context. ${ }^{8}$ Intuitively, in this context, $g(7)$ is that situation picked out by expressions such as "the outcome of the 2016 US presidential election," or "the Trump victory." The pronoun can be assumed to refer, then, to the situation that exemplifies the proposition denoted by "Trump won the election."

Tunç's belief happens to be false here. This is not an issue in the present system. The non-factivity of bil-makes it such that the situation that the belief is about need not be the kind of situation that the attitude holder believes it to be.

What if the context is not so specific? Different options are available at this stage. I could say "You wanna know something funny?" and follow up with (1b). In this case, I am asking my addressee to accommodate the appropriate res situation. My utterance of the attitude report provides the necessary information to do this effortlessly and unambiguously. But I could also have said "I'm not sure about the outcome of the election," and then uttered (1b). This case is trickier, and I will not decide between the two following options (they might both be available). It could be that the res situation contains the relevant circumstances of the presidential election removed of its actual winner. The situation we are talking about, then, is one that exemplifies the proposition denoted by "One of Hillary or Trump won the election." Else, it could be that the res argument is existentially closed. In this case, the truth conditions of (1b) are as in (13). These read "there is a situation which Tunç is acquainted with through (the existentially introduced) $R$, and he believes of that situation that Hillary won."

$$
\exists R\left[\exists s\left[R\left(t, s, w_{0}\right) \wedge \forall w^{\prime}\left[w^{\prime} \in D O X_{t, w_{0}} \rightarrow \operatorname{win}\left(l s^{\prime}\left[R\left(t, s^{\prime}, w^{\prime}\right)\right]\right)(h)\right]\right]\right]
$$

These two strategies for recovering a res are useful for accounting for non-factive bil- reports with first person attitude holders. Indeed, if I say (14) and I have in mind the actual Trump victory, I would be contradicting myself. However, if the res is 'underspecified' or existentially closed, no contradiction arises. I am simply stating that I am acquainted with a situation of which I believe that it is a Hillary victory.

8 I leave for further research the issue of whether an antecedent for res pronoun can be found in the text rather than in the common ground. The following contrast suggests that pronouns are not easily anaphoric on situations mentioned in the text. "Trump won. It was an unhappy event." "Mary claims that Trump won. \#It was an unhappy event." 
(14) Ben [Hillary kazandı diye] biliyorum.

$1 \mathrm{~s}$ H. won DIYE know. $1 \mathrm{~s}$

I believe that Hillary won.

A word now has to be said about the acquaintance relation that relates the attitude holder to the res introduced as discussed. Here is a context that provides one:

(15) The mock news report: Tunç is watching a news report about the 2016 US presidential election. Although Trump won, the report states that Hillary did. This is (reasonably) what Tunç comes to believe.

$\llbracket R_{\text {news }} \rrbracket=\lambda x . \lambda s . \lambda w . x$ watches a news report about $s$ at $w$

The Trump victory satisfies this relation in the actual world. In worlds where Hillary won, the Hillary victory there will satisfy the relation. The relation given in (15) acts like a prism, presenting one situation of the world as another.

\subsection{Deriving the factive alternant}

Example (1a) is repeated below, where bil- introduces a factive attitude report. The truth conditions for (1a) need to come out such that the existence of a Hillary victory is globally implied, in addition the belief that Hillary won being asserted. In other words, the res and the belief must "match." An informal paraphrase of (1a)'s target truth conditions is given in (16).

(1a) Tunç [Hillary'nin kazan-dığın-1] biliyor.

T. H. win-NMZ-ACC knows

Tunç knows that Hillary won.

(16) Tunç believes of [res the Hillary victory ] [belief that Hillary won ]

(Assumption: Hillary won the election.)

These truth conditions, however, cannot be the result of accidentally valuing the res in such a way that it refers to the Hillary victory. ${ }^{9}$ This is discussed below. Hence, an additional derivational step is required to arrive at (16), which is shown in (17).

9 This point is usually omitted in the textbook analysis of "know" e.g., in Percus (2006), but not in more sophisticated analyses (Kratzer 2002). Assume that $\llbracket k n o w \rrbracket\left(w_{s}\right)\left(p_{s t}\right)\left(x_{e}\right)$ is defined iff $p$ is true at $w$, and true iff $x$ believes $p$ at $w$ (the textbook analysis). The function does not evaluate to false or is not undefined in cases where the belief is accidentally true, which goes against our intuition. 
Attitudes with(out) true belief

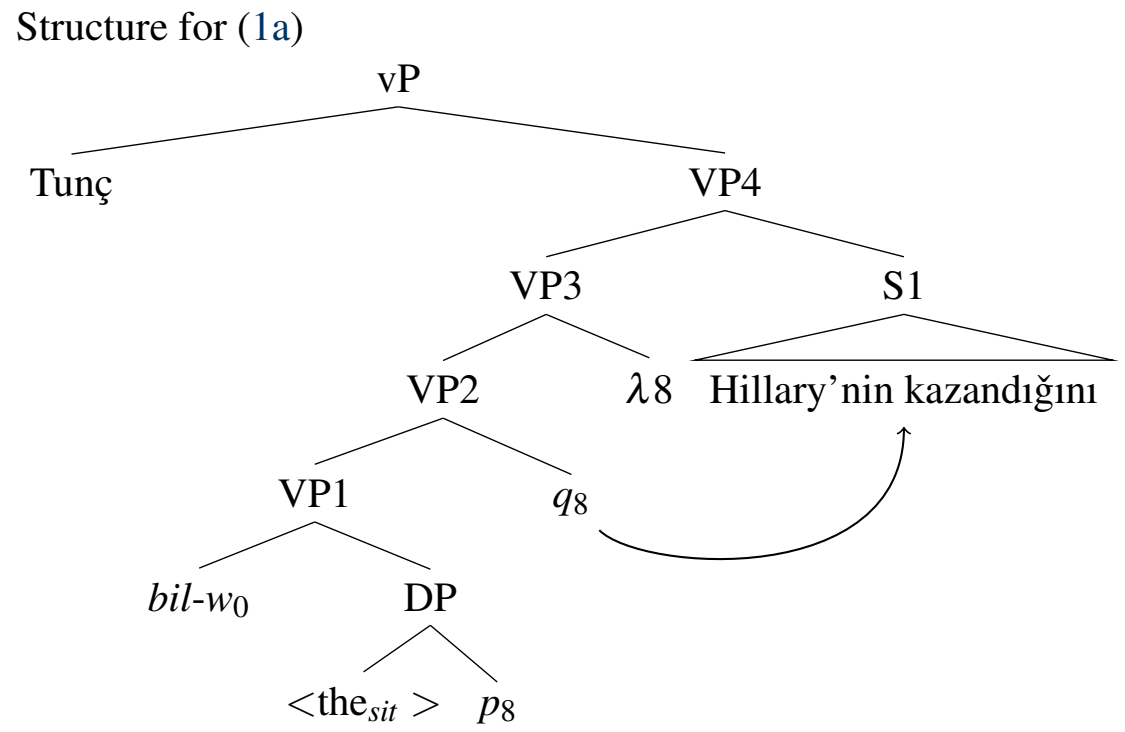

Here, the res argument is saturated by a covert definite description. A variable ranging over propositions, noted $p_{8}$, is introduced within. It composes with a definite

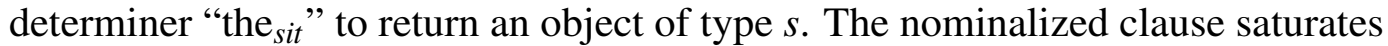
bil-'s proposition argument and raises. It leaves a trace, $q_{8}$, of type $s t$, and creates a binder, $\lambda 8$. This binder binds both the trace, as usual, and the proposition variable introduced within the res argument. ${ }^{10}$

Natural languages have ways of referring to particular situations. "World War II," or the subject of the sentence "The quick eating of that apple took place on July 16," illustrate a couple (Portner 1992). Given this, it seems natural to think that there are definite determiners that compose with a proposition to return the unique relevant situation that satisfies a proposition. But, situations are notoriously difficult to count, and a general unicity condition over them is not trivial to formulate (von Fintel 2005; Kratzer 2017). I will make use of Kratzer's notion of exemplification here, while bearing in mind that there are propositions that might not have a unique exemplifier. ${ }^{11}$ Additional machinery will be needed for such cases. In the definition of "the sit " in (18), $\mathrm{EX}(s, p)$ stands for " $s$ exemplifies $p$. ."

$$
\llbracket \text { the }_{s i t} \rrbracket^{g}=\lambda p_{s t}: \exists ! s[\operatorname{EX}(s, p)] . \iota s^{\prime}\left[\operatorname{EX}\left(s^{\prime}, p\right)\right]
$$

The structure in (17) is interpreted as follows. At the node labeled VP3, both the description of the res and the proposition introducing the content of the belief are

10 Nothing prevents us from saturating the res argument with a definite description in the non-factive structure proposed for (1b). Doing so, however, will not result in factive truth conditions given that tensed clauses are not able to bind the proposition variable introduced by the definite description.

11 Kratzer's "There is mud" is one such proposition. Take Mud to be some situation that exemplifies the proposition. The proposition is also exemplified by every subsituation of Mud. A notion of maximal situation is, I believe, required to capture cases like this. But this too might not be enough in general. 
abstracted over. This is spelled out in (19a). At the node labeled VP4, the (raised) nominalization simultaneously values the res description and the belief proposition, in (19b). The rest proceeds standardly and truth conditions in (19c) are derived.

a. At node VP3, abstraction over res description and belief: if defined, $\llbracket \mathrm{VP} 3 \rrbracket=\lambda \phi_{s t} \cdot \lambda x \cdot \exists R\left[R\left(x, \imath s[\mathrm{EX}(s, \phi)], w_{0}\right) \wedge\right.$

$$
\left.\forall w^{\prime}\left[w^{\prime} \in D O X_{x, w_{0}} \rightarrow \phi\left(l s^{\prime}\left[R\left(x, s^{\prime}, w^{\prime}\right)\right]\right)\right]\right]
$$

b. At VP4, covaluation of res description and belief:

$$
\begin{aligned}
& \text { if defined, } \llbracket \mathrm{VP} 4 \rrbracket=\lambda x \cdot \exists R\left[R\left(x, l s\left[\mathrm{EX}\left(s, \lambda s^{\prime} \cdot \operatorname{win}\left(s^{\prime}\right)(h)\right)\right], w_{0}\right) \wedge\right. \\
& \left.\qquad \forall w^{\prime}\left[w^{\prime} \in D O X_{x, w_{0}} \rightarrow \operatorname{win}\left(l s^{\prime}\left[R\left(x, s^{\prime}, w^{\prime}\right)\right]\right)(h)\right]\right] \\
& \text { c. Final truth conditions } \\
& \text { if defined, } \llbracket \mathrm{vP} \rrbracket=\llbracket \mathrm{VP} 4 \rrbracket(\llbracket \text { Tunç } \rrbracket)=1 \text { iff } \\
& \exists R\left[R\left(t, \imath s\left[\mathrm{EX}\left(s, \lambda s^{\prime} \cdot \operatorname{win}\left(s^{\prime}\right)(h)\right)\right], w_{0}\right) \wedge\right. \\
& \left.\forall w^{\prime}\left[w^{\prime} \in D O X_{t, w_{0}} \rightarrow \operatorname{win}\left(l s^{\prime}\left[R\left(t, s^{\prime}, w^{\prime}\right)\right]\right)(h)\right]\right]
\end{aligned}
$$

These read: "There is an $R$, s.t. Tunç is acquainted through $R$, at $w_{0}$, with the situation that exemplifies the proposition that Hillary won, and believes of the situation $s^{\prime}$ that he is acquainted with through $R$ that Hillary won." The truth conditions of a factive attitude report require, globally, that the holder's belief be true, and that it be true in a certain way. This is achieved in the previous derivation, by making it a feature of the composition to force the res to be a situation that satisfies the belief proposition.

\section{General discussion}

\subsection{Generating the factive inference}

In this system, the factive inference arises from the interaction of two components. First, bil-introduces an "unspecified" res, which the attitude holder is acquainted with at the world of evaluation. Second, the nominalization provides a proposition $p$, which the res is made to satisfy in the composition. From the fact that the res is part of the world of evaluation, it follows that part of the world of evaluation satisfies $p$. In fact, assuming that propositions of natural language are "persistent," in the sense of Kratzer (1989), $p$ is also satisfied by any super-situation of the res, and in particular by the world of evaluation. This is our factive inference.

The factive inference is predicted to project because the res is introduced within a definite description headed by a determiner that introduces an existence presupposition, defined in (18). This is in line with attempts to reduce the inference to an effect of definiteness (Hanink \& Bochnak 2017). A crucial difference here is that I do not directly and uniformly compose nominalized embedded clauses with the $r$ operator, opting instead for the two step process described above. Uniformly closing off nominalizations' situation argument with $\imath$ makes the unwelcome prediction that 
all nominalizations should denote facts, contrary to observation. A second difference is that I do not use content individuals. Such individuals are sometimes thought to be the real complements of belief verbs, and the denotation of the embedded clause is predicated of their content. This reduces the surface form "S knows that $p$ " to the underlying "S knows the content individual $x$ whose content is $p$." The reason for not adopting this view is that $x$ could be any kind of content individual, a piece of news, a rumor, etc., and not necessarily a fact.

Turning to the non-factive alternant, bil-introduces a res in its derivation as well, which was saturated by a referential pronoun. The pronoun is valued through the assignment function. Then, if a value is provided, the derivation proceeds; If not, the attitude report is predicted to be undefined. Compare this to an out-of-the blue utterance with a novel pronoun "She walked in." This is odd unless the denotation of "she" is contextually provided. Should this condition on definedness be a concern for non-factive attitude reports? No. The referential pronoun strategy assumes that the interlocutors have mutual knowledge of the situation under discussion as the object of the attitude holder's belief (or at least that the addressees are in a position to accommodate one.) This will lead to presupposing the existence of some situation, but not necessarily of one that makes the belief proposition true.

\subsection{Syntactic questions}

The first question concerns bil-'s two internal arguments, the res and the belief proposition. The situation argument was covert in the derivations above. An example like (20b) is tentative evidence that the res may be overtly realized and that the twoargument approach is on the right track. The assertion in (20a) introduces a salient situation. An overt DP is simultaneously realized with the embedded clause in (20b), anaphoric on that situation and understood to be the object of Tunç's belief.

a. Trump kazand1. Trump won.

b. Tunç $\{\underline{\mathrm{o}-\mathrm{nu}}, \underline{\mathrm{o} \text { durum-u}}\} \quad$ [Hillary kazandı diye] biliyor. Tunç 3S-ACC that situation-ACC Hillary won DIYE knows

Tunç believes of $\{$ that, that situation $\}$ that Hillary won.

The underlined DPs are good candidates for being the realization of the res argument. It is possible that the DP is proleptic or an exceptionally case marked argument. Further research should shed light on the matter.

The evidence is tentative because it is starkly ungrammatical to express the res with a nominalization, though it is uniformly assumed to be in the structure. (The ungrammaticality of the sentence does not depend on the truth/falsity of the belief.) 
c. Tunç (*o-nu) [\{Hillary’nin, Trump'ın $\}$ kazandığını] biliyor. Tunç 3S-ACC H. T. Won.NMZ knows Intended: Tunç knows of that that \{Hillary, Trump\} won.

At this stage, we could assume for (20) that the res and the nominalization compete for case, that the nominalization wins, being the higher of the two at some level of representation, and that caseless DPs, though licensed, may not be pronounced. (Note that this would not prevent DPs that do have case from being unpronounced.)

The second and third questions concern raising the nominalization in the derivation of the factive alternant, and binding a variable over propositions located within the res argument. Tensed clauses were assumed not to undergo this operation, as they are not observed to give rise to the factive inference.

Turkish direct objects are either bare nominals or overtly marked for the accusative ("Differential Object Marking"). Bare nominals are thought to occupy a lower position than accusative marked nominals (Erguvanl1 1984). The argument comes from examples like (21), where the former must linearly follow, but the latter must linearly precede, low manner adverbs. ${ }^{12}$ Assuming a unique base-generation position and a grammar without lowering, accusative objects must raise.

$\begin{array}{llll}\text { Tunç (*bira) } & \text { hılı } & \text { (bira) } & \text { içti. } \\ \text { Tunç (bira-y1) } & \text { hılı } & \text { (*bira-y1) } & \text { içti. } \\ \text { Tunç beer\{.NOM,-ACC }\} & \text { quickly beer\{.NOM,-ACC }\} & \text { drank } \\ \text { Tunç drank }\{\text { beer, the beer\} quickly. } & \end{array}$

This constitutes a test for the relative height of embedded clauses. The data in (22) shows that the test reveals no difference between the height of nominalizations and tensed clauses. Both must precede the manner adverb. (Nominalizations, like proper names and pronouns, do not occur as bare direct objects.)
a. (Kazandığın-1) hızlı (*kazandığın-1) anladı. win.NMZ-ACC quickly win.NMZ-ACC understood
b. (Kazandı diye) hizli (*kazandı diye) anladı. won DIYE quickly won DIYE understood

She quickly understood that she won. ((22a) factive, (22b) non-factive)

While this pattern is evidence that nominalizations do raise, it does not rule out the possibility that tensed clauses do not. Example (20b) suggests that what raises in sentences like (20b) and (22b) is not the tensed clause but the res argument. Leaving the status of tensed clauses of further research, it suffices for present purposes to think that nominalizations must raise, and that only they may bind.

12 Non-neutral topic/focus assignment ameliorates the starred orders (Gračanin-Yuksek \& İşsever 2011). 
Attitudes with(out) true belief

\subsection{Bind the res!}

In a context such as (23) where the embedded proposition is true, it is perfectly acceptable to utter the factive alternant, but it is odd to utter the non-factive one. ${ }^{13}$

(23) Context: Hillary won. Tunç has closely followed coverage of this outcome and came to believe that Hillary did win.

$$
\begin{aligned}
& \checkmark \text { Tunç [Hilari’nin kazandığını] biliyor. (=(1a)) } \\
& \text { \# Tunç [Hillary kazandı diye] biliyor. (=(1b)) } \\
& \text { Tunç that Hillary won know } \\
& \text { Tunç }\{\checkmark \text { knows, \#believes }\} \text { that Hillary won. }
\end{aligned}
$$

The semantics for the non-factive alternant is such that the res is contextually valued to that situation that exemplifies the proposition that Hillary won. Nothing prevents this from happening. The semantics for the factive alternant gives the res the same value, but by binding a proposition variable introduced within the res with the nominalization. In short, the difference between (1a) and (1b) is that in the LF for the former, the res is bound.

The contrast between (1a) and (1b) in context (23) can be accounted for if there is a preference for binding over coreference in contexts where binding is licensed. This preference is expressed by the interpretive constraint in (24).

Bind the res if you can!

If the LFs of two attitude reports introduced by bil- only differ in that, in one, the res is bound, pick the LF in which the res is bound.

This constraint only applies in cases where an LF with binding competes with an LF with coreference. LFs with a bound res argument require that the embedded proposition be true. As a result, a competition only arises in contexts where the embedded proposition is true. Then, the LF with binding rules out the LF without. That is, (1a) rules out (1b).

Section 3.3 presented a structure where the res was bound by the nominalization. The relevant portion of this structure is given in (25a), where $p_{8}$ and $q_{8}$ are coindexed. There is an alternative LF, presented in (25b), where $p$ and $q$ are contra-indexed: There the res is unbound.

$$
\begin{aligned}
& \text { a. }[\mathrm{NMZ}-\mathrm{belief} \\
& \lambda s \cdot \lambda w \cdot w i n(s)(w)(h)]\left[\lambda 8\left[p_{8}\left[\left[\text { res the } q_{8}\right] \text { bil-wo } w_{0}\right]\right]\right. \\
& \text { b. [NMZ-belief } \lambda s \cdot \lambda w \cdot w i n(s)(w)(h)]\left[\lambda 8\left[p_{8}\left[\left[\text { res the } q_{9}\right] \text { bil-w } w_{0}\right]\right]\right]
\end{aligned}
$$

13 This is strongly reminiscent of anti-presupposition, see Percus (2006) among others. Note, informally, that a principle like Maximize Presupposition! cannot directly be used to account for the contrast. Both (1a) and (1b) presuppose the existence of a Hillary victory, though by slightly different means. 
In contexts where (25a) is licensed, (25b) is blocked by (24) in the same way (1b) is blocked. But there are contexts in which (25a) is not licensed, specifically ones where the embedded proposition is not true. In such contexts, (24) is not operative. This allows for the possibility that there should be non-factive attitude reports introduced by bil-, even when the verb composes with a nominalization. This is what we find.

Observe the contrast between (26a) and (26b). Sentence (26a) illustrates the kind of factive attitude report that we have been concerned with up to now, but with an additional piece of information: The nuclear pitch accent (indicated by caps and abbreviated as 'NPA') on these reports is most naturally realized on the matrix predicate. ${ }^{14}$ Sentence (26b) involves the same string, but with the NPA realized in an embedded position. This sentence can be interpreted as non-factive.

$$
\begin{aligned}
& \text { a. \# Tunç [Hilari’nin kazandığını] BİLIYYOR, ama Trump kazandı. } \\
& \text { b. } \checkmark \text { Tunç [HİLARI'NİN kazandığını] biliyor, ama Trump kazandı. } \\
& \begin{array}{llll}
\text { T. H. Hin.NMZ know but T. } & \text { Hon }
\end{array}
\end{aligned}
$$

Tunç $\{\#$ knows, believes $\}$ that Hillary won, but Trump did.

The effect of the position of the NPA on the availability of the factive inference is not yet well understood. Within the present proposal, the availability of non-factive readings with nominalized clauses under bil-is captured if we assume, as in (25b), that the res can remain unbound even in the presence of a binder in the structure. Given that the position of the NPA is associated with the position at which focus alternatives are calculated (Krifka 2008; Roberts 2012), I temporarily propose the principle in (27). The answer to how or why this principle operates will have to await further investigation. Beaver (2010); Abrusán (2011) and Simons, Beaver, Roberts $\&$ Tonhauser (2015) notice a suspiciously similar pattern, but, for projection.

(27) Embedded focus overrides the preference for binding the res.

A question arises at this stage as to whether the factive inference is semantically encoded in Turkish attitude reports at all. There is a reason for thinking that it is. Context (28) makes the embedded proposition is true. Four sentences are provided: bil- and düşün- with nominalizations and with tensed clauses. Of these options, only bil- with a nominalization is perfectly acceptable, the rest are odd.

14 The interested reader is invited to consult Kamali (2011) and İpek (2015) about the phon \{ological, etic \} realization of focus in Turkish. The presentation of the pattern in (26) is again simplified: There are ways of constructing examples with embedded focus where the factive inference is available. It is unclear whether there are bone fide examples with matrix focus, with a nominalization, and without the factive inference. Potential candidates all seem to involve tensed clause embedding. 
Attitudes with(out) true belief

(28) The know it already: Someone comes up to me and says "Hillary won."

a. Hillary'nin kazandığını $\{\checkmark$ biliyorum, \#düşünüyorum $\}$.

H. win.NMZ I know I think

b. \#[Hillary kazandı diye] \{biliyorum, düşünüyorum .

H. won DIYE I know I think

I $\{$ know, \#believe, \#think\} that Hillary won.

Similar contrasts are traditionally analyzed by assigning a presuppositional LF to the felicitous attitude report, which competes and wins against the non-presuppositional LFs of the infelicitous reports (Percus 2006). To capture the contrast between the two attitude reports with bil-, we had to make use of a slightly different mechanism than the one proposed in the literature ("Bind the res if you can!"). The point is that we have a way of explaining these contrasts if bil- with a nominalization is at least sometimes associated with a semantic representation that is veridical or presuppositional. A similar point can be made based on the projection facts shown in (7). In sum, without a special semantic representation associated with factive attitude reports, we lack an explanation for why the the non-factive attitude reports cannot be used factively, or at least as systematically. ${ }^{15}$

\section{Concluding remarks: Justified Belief}

In Turkish, predicates like bil- give rise to both factive and non-factive attitude reports. This alternation can be captured by assuming that these predicates introduce a non-factive de re belief relation about situations and that, under certain cirumstances, the res is forced in the semantic composition to satisfy the belief proposition.

I conclude this paper by a comparison between non-factive reports introduced by bil-, and ones introduced by verbs like düşün- ("think") and san- ("believe"). A simple linguistic model for knowledge ascription is the ascription of true belief. Factive uses of bil- conform to this model. What of its non-factive uses? Do they reduce to the attribution of plain belief? This expectation is not borne out.

Non-factive bil-, düşün-, and san- reports are judged in the two contexts in (29). In (29a), Tunç's belief is solely grounded in his obsession. The bil-report is false here, while the düşün- and san- reports are true. In context (29b), Tunç's belief is motivated by the guards' celebration. All three reports are true.

15 Hazlett $(2010,2012)$ proposes to dispose of semantic factivity in favor of pragmatic presupposition. The move is not unappealing, but an explanation is yet lacking as to why "know" can so easily be used to presuppose its complement, but not, for example, "think." Even pragmatic approaches to presupposition like Stalnaker's (1973/1999), Abusch's (2002; 2010), etc., make use of the assumption that "know" is a veridical operator, which is a property of semantic representations. 
(29) Tunç is in solitary confinement with no information about the world.

a. The monomaniac: He is obsessed by Hillary and accepts no state of the world where she has not won the election.

b. The monomaniac + the prank: He is obsessed by Hillary and accepts no state of the world where she has not won the election. In addition, the guards loudly celebrate a Hillary victory outside his door.

(1b) Tunç [Hillary kazan-dı diye] biliyor.

T. H. win-PST DIYE knows

Tunç believes that Hillary won. $\quad$ (29a):F ; (29b):T

(30) Tunç [Hillary kazand1] \{sanıyor, diye düşünüyor $\}$.

T. H. won believes DIYE thinks

Tunç \{believes, thinks $\}$ that Hillary won. $\quad$ (29a):T ; (29b):T

Comparing the truth of (30) and the falsity of (1b) in context (29a) suggests that nonfactive attitude reports introduced by bil- are stronger than plain belief or thought reports: Non-factive bil- reports cannot be reduced to simple belief ascription. The present account can capture this contrast if it is assumed either that context (29a) does not provide any acquaintance relation between the attitude holder and the outcome of the election, or that if one can be found, it is not a suitable one. The prank context (29b), in contrast, does provide one: The guards' celebratory remarks.

From the perspective of knowledge defined as Justified True Belief, this is a curious result. Is a "justification" requirement what remains when bil- is removed of the factive presupposition? This is a live option, based on the contextual information that licenses bil- in (29b). ${ }^{16}$ Further research is required to thoroughly test these attitude reports in Gettier and other similar contexts. Although an acquaintance relation is suitable to capture some forms of justification, it might be unable to encode "reliability" as discussed by Kratzer (2002) and others.

\section{References}

Abrusán, Márta. 2011. Predicting the presuppositions of soft triggers. Linguistics and Philosophy 34(6). 491-535. doi:10.1007/s10988-012-9108-y.

Abusch, Dorit. 1994. Sequence of tense revisited: Two semantic accounts of tense in intensional contexts. Ellipsis, tense and questions 87-139.

Abusch, Dorit. 2002. Lexical alternatives as a source of pragmatic presuppositions. In Semantics and Linguistic Theory (SALT) 12, 1-19. doi:10.3765/salt.v12i0.2867.

16 Bearing in mind that the JTB model for knowledge is criticized (Gettier 1963), and that it is not obvious that one can study natural language expressions like bil- or "know" with the hope of uncovering truths about the concept of knowledge (Hazlett forthcoming). 
Attitudes with(out) true belief

Abusch, Dorit. 2010. Presupposition triggering from alternatives. Journal of Semantics 27(1). 37-80. doi:10.1093/jos/ffp009.

Beaver, David. 2010. Have you noticed that your belly button lint color is related to the color of your clothing? In R. Bauerle, U. Reyle \& T. E. Zimmermann (eds.), Presuppositions and discourse: Essays offered to Hans Kamp, 65-99. Elsevier.

Charlow, Simon \& Yael Sharvit. 2014. Bound 'de re' pronouns and the LFs of attitude reports. Semantics and Pragmatics 7(3). 1-43. doi:10.3765/sp.7.3.

Şener, Serkan. 2008. Non-Canonical Case Licensing is Canonical: Accusative Subjects of CPs in Turkish. Ms. University of Connecticut.

Erguvanl1, Eser Emine. 1984. The Function of Word Order in Turkish Grammar. 106. University of California Press.

von Fintel, Kai. 2005. How to count situations (notes towards a user's manual). Ms. MIT http://mit.edu/fintel/fintel-2005-counting.pdf.

Gettier, Edmund L. 1963. Is Justified True Belief Knowledge? Analysis 23(6). 121-123. doi:10.1093/analys/23.6.121.

Glass, Lelia. 2016. The negatively biased Mandarin belief verb yiwei. Ms. Stanford http://ling.auf.net/lingbuzz/002600/.

Gračanin-Yuksek, Martina \& Selçuk İşsever. 2011. Movement of bare objects in Turkish. Dilbilim Araştırmaları 22(1). 33-49.

Grimshaw, Jane. 2015. The light verbs say and SAY. In Ida Toivonen, Piroska Csúri \& Emile van der Zee (eds.), Structures in the Mind: Essays on Language, Music, and Cognition, MIT Press.

Hanink, Emily \& Ryan Bochnak. 2017. Factivity and two types of embedded clauses in Washo. In Andrew Lamont \& Katerina Tetzloff (eds.), North East Linguistic Society (NELS) 47, GLSA.

Hazlett, Allan. 2010. The myth of factive verbs. Philosophy and Phenomenological Research 80(3). 497-522. doi:10.1111/j.1933-1592.2010.00338.x.

Hazlett, Allan. 2012. Factive presupposition and the truth condition on knowledge. Acta Analytica 27(4). 461-478. doi:10.1007/s12136-012-0163-3.

Hazlett, Allan. forthcoming. Theory of knowledge without (comparative) linguistics. In M. Mizumoto, S. Stitch \& E. McReady (eds.), Epistemology for the Rest of the World, Oxford University Press.

Heim, Irene. 1988. On the projection problem for presuppositions. In D. Flickinger et al. (ed.), West Coast Conference on Formal Linguistics (WCCFL) 2, 114-125. Stanford University Press.

Heim, Irene. 1994. Comments on Abusch's theory of tense. In Hans Kamp (ed.), Ellipsis, tense, and questions, 143-170.

Hintikka, Jaakko. 1962. Knowledge and belief: An introduction to the logic of the two notions. Cornell University Press.

Holton, Richard. 2017. Facts, factives, and contrafactives. Aristotelian Society 
Supplementary Volume 91(1). 245-266. doi:10.1093/arisup/akx003.

Hooper, Joan B. 1975. On assertive predicates. Syntax and Semantics 4. 91-124.

İpek, Canan. 2015. The phonology and phonetics of Turkish intonation: USC PhD dissertation.

Kamali, Beste. 2011. Topics at the PF interface of Turkish: Harvard University PhD dissertation.

Karttunen, Lauri. 1971. Implicative verbs. Language 47(2). 340-358. doi: $10.2307 / 412084$.

Kastner, Itamar. 2015. Factivity mirrors interpretation: The selectional requirements of presuppositional verbs. Lingua 164. 156-188. doi:10.1016/j.lingua.2015.06.004.

Kierstead, Gregory. 2013. Shifted indexicals and conventional implicature: Tagalog akala 'falsely believe'. Semantics and Linguistic Theory (SALT) 23.

Kiparsky, Paul \& Carol Kiparsky. 1970. Fact. In Manfred Bierwisch \& Karl E. Heidolph (eds.), Progress in Linguistics, The Hague: Mouton.

Korotkova, Natalia. 2016. Heterogeneity and uniformity in the evidential domain: UCLA PhD dissertation.

Kratzer, Angelika. 1989. An investigation of the lumps of thought. Linguistics and Philosophy 12(5). 607-653. doi:10.1007/BF00627775.

Kratzer, Angelika. 1998. Scope or pseudoscope? Are there wide-scope indefinites? In Susan Rothstein (ed.), Events and grammar, 163-196. Springer. doi:10.1007/978-94-011-3969-4_8.

Kratzer, Angelika. 2002. Facts: Particulars or information units? Linguistics and philosophy 25(5). 655-670. doi:10.1023/A:1020807615085.

Kratzer, Angelika. 2006. Decomposing attitude verbs. Talk presented at the workshop in honor of Anita Mittwoch. The Hebrew University of Jerusalem. July 4, 2006. https://works.bepress.com/angelika_kratzer/15/.

Kratzer, Angelika. 2017. Situations in natural language semantics. In Edward N. Zalta (ed.), The Stanford Encyclopedia of Philosophy, Metaphysics Research Lab, Stanford University winter 2017 edn.

Krifka, Manfred. 2008. Basic notions of information structure. Acta Linguistica Hungarica 55(3-4). 243-276. doi:10.1556/ALing.55.2008.3-4.2.

Lewis, David. 1979. Scorekeeping in a language game. Journal of philosophical logic 8(1). 339-359. doi:10.1007/BF00258436.

Moulton, Keir. 2009. Natural selection and the syntax of clausal complementation: UMass, Amherst PhD dissertation.

Özyıldız, Deniz. 2012. When I is not me: A preliminary account of indexical shifting in Turkish. Unpublished manuscript, ENS Paris.

Özy1ldız, Deniz. 2016. Knowledge reports without truth. In Köllner Marisa \& Ziai Ramon (eds.), European Summer School in Logic, Language, and Information 
Attitudes with(out) true belief

(ESSLLI) 2016 student session, 184-196.

Percus, Orin. 2000. Constraints on some other variables in syntax. Natural Language Semantics 8. 173-229. doi:10.1023/A:1011298526791.

Percus, Orin. 2006. Antipresuppositions. In A. Ueyama (ed.), Theoretical and empirical studies of reference and anaphora: Toward the establishment of generative grammar as an empirical science, Japan Society for the promotion of science.

Percus, Orin \& Uli Sauerland. 2003. On the LFs of attitude reports. In Matthias Weisgerber (ed.), Proceedings of Sinn und Bedeutung (SuB) 7, Universität Konstanz.

Portner, Paul Howard. 1992. Situation theory and the semantics of propositional expressions: UMass, Amherst $\mathrm{PhD}$ dissertation.

Quine, Willard V. 1956. Quantifiers and propositional attitudes. The Journal of Philosophy 53(5). 177-187. doi:10.2307/2022451.

Roberts, Craige. 2012. Information Structure: Towards an integrated formal theory of pragmatics. Semantics and Pragmatics 5. 1-69. doi:10.3765/sp.5.6.

Schulz, Petra. 2003. Factivity: Its Nature and Acquisition. Max Niemeyer Verlag: Tübingen.

Şener, Nilüfer Gültekin \& Serkan Şener. 2011. Null subjects and indexicality in Turkish and Uyghur. In Andrew Simpson (ed.), Workshop on Altaic Formal Linguistics (WAFL) 7, 269-284.

Simons, Mandy, David Beaver, Craige Roberts \& Judith Tonhauser. 2015. The Best Question: Explaining the Projection Behavior of Factives. Discourse Processes 54(3). doi:10.1080/0163853X.2016.1150660.

Stalnaker, Robert. 1973/1999. Pragmatic presuppositions. In Context and Content, 45-62. Oxford University Press.

White, Aaron Steven. 2014. Factive-implicatives and modalized complements. In Jyoti Iyer \& Leland Kusmer (eds.), North East Linguistic Society (NELS) 44, UMass, Amherst. GLSA Publications.

\footnotetext{
Author

Deniz Özyıldız

N408 Integrative Learning Center

650 North Pleasant Street

University of Massachusetts Amherst

Amherst, MA 01003-1100

dozyildiz@umass.edu

http://deniz.fr
} 